Volume 8

Issue 3 Humanitarian Technologies and

Genocide Prevention

October 2014

\title{
Hidden Genocides: Power, Knowledge, Memory
}

Uğur Ümit Üngör

Institute for War, Holocaust and Genocide Studies, Amsterdam

Follow this and additional works at: https://digitalcommons.usf.edu/gsp

\section{Recommended Citation}

Ümit Üngör, Uğur (2014) "Hidden Genocides: Power, Knowledge, Memory," Genocide Studies and Prevention: An International Journal: Vol. 8: Iss. 3: 101-102.

DOI:

http://dx.doi.org/10.5038/1911-9933.8.3.9

Available at: https://digitalcommons.usf.edu/gsp/vol8/iss3/11

This Book Review is brought to you for free and open access by the Open Access Journals at Digital Commons @ University of South Florida. It has been accepted for inclusion in Genocide Studies and Prevention: An International Journal by an authorized editor of Digital Commons @ University of South Florida. For more information, please contact digitalcommons@usf.edu. 


\title{
Hidden Genocides: Power, Knowledge, Memory, edited by Alexander Laban Hinton, Thomas La Pointe, and Douglas Irvin-Erickson, Newark: Rutgers University Press, 2013, 230pp \$80.00 (hbk), \$28.95 paperback
}

\author{
Reviewed by Uğur Ümit Üngör \\ Associate Professor, Institute for War, Holocaust and Genocide Studies, Amsterdam
}

\begin{abstract}
This book begins with an interesting problematization: why do some genocides become prominent in academic research, public awareness, and political recognition, whereas others do not? Is it a question of power making knowledge in public consciousness (i.e. political), or do neutral scholars mark some events as genocide due to their specific features (i.e. academic)? The editors have assembled a diverse range of chapters that all address these questions for particular cases, countries, and regions, and all offer different answers to them. Due to the common theme underlying each chapter, the book does not suffer from incoherence vexing many edited volumes.

Dirk Moses examines the long and arduous process of the establishment of the Canadian Museum for Human Rights (CMHR) in Winnipeg. As Ukrainian, Armenian, Jewish, and Palestinian community advocates scuffled to secure a prominent place in the museum, they forgot about the communities that were arguably entitled to primacy in terms of representation: the native Canadians. The glaring disregard for the very community on whose land the museum would stand is a comment on the self-centered preoccupations of diaspora community organizations. Elisa von Joeden-Forgey's fresh chapter unmasks the legal categories produced in Imperial Germany to deal with Eingeborenen ("natives"), a category of human beings who were not protected by the state and against the state - such as floggings in Germany's colonial possessions. Hiding mass violence could thus be a function of the legal system.

Daniel Feierstein breaks down the popular belief that genocide is predicated upon a binary system of bad perpetrators versus good victims. He argues that since genocide is about destroying identity, "any attempt to tackle genocidal social practices must begin with this construction of identity and otherness" (p.75). Argentina is used as an example of genocide in which the government destroys its own population. Theorizing from the Soviet Union or the Khmer Rouge would have elucidated his point even further. Donna Lee-Frieze's chapter on the Stolen Generations argues that the kidnapping of Aborigine children, kept behind a veneer of decency by the Australian government, was a genocide by absorption. Like Feierstein, she uses Levinas' philosophy of Self and Other to examine that genocide as a form of "noncorporeal violence" (p.91).

Most chapters offer a new perspective or a fresh interpretation, but Walter Richmond's chapter also provides empirical evidence. It sheds light on a genocide that remained hidden behind another hidden genocide: the 1820 Russian destruction of Kabardia, in which an entire tribal society was comprehensively destroyed, partially expelled, and forever subjugated. Based on painstaking research on Russian sources, the chapter also convincingly suggests that the British government helped 'hide' the genocide by forgetting and ignoring it. (In much of this, one hears the echoes of how Britain and the United States ignored and silenced the 1940 Katyn massacre due to the expediency of the alliance against Hitler.)

Adam Jones untangles the clew of violent episodes in the Great Lakes region, in which the 1994 Rwandan genocide has become canonical, at the expense of other, similar violence. He is right in arguing that comparative research can de-contextualize a genocide from its broader environment of mass political violence, and warns against bracketing off the Rwandan genocide from a) the prehistory of multi-directional violence in Rwanda or b) the genocides in neighboring countries such as Zaire/DRC or Burundi. Throwing his caution to the wind may cause us to lose track of connections, continuity, and spillover. Alex Hinton's deeply touching chapter illustrates "how complicated histories are contested and depicted in reductive ways" (p.153). It revolves around the devastating testimony of Chlat, a Cambodian man who lost most of his family, survived the genocide himself, but fell victim to AIDS 30 years later. The chapter clarifies how the liberating Vietnamese government shifted away from the Khmer Rouge, but also adopted some of its rhetoric, and diverted attention away from the genocide mostly for geopolitical reasons. Yes, the Khmer Rouge had annihilated the Vietnamese minority in Cambodia, but at least they had been anti-Western.

The book has some minor flaws: the chapter by Chris Mato Nunpa is not a research essay, but a vehement political denunciation of the United States. The chapter by Hannibal Travis makes some good points, but is generally overstated, and somewhat pharisaical. In a nutshell, it argues: "Scholars of the Armenian genocide are complicit in an ongoing concealment of the Assyrian and Greek genocides" (p.172). The chapter neither
\end{abstract}

Uğur Ümit Üngör, "Book Review. Hidden Genocides: Power, Knowledge, Memory. Edited by Alexander Laban Hinton, Thomas La Pointe, and Douglas Irvin-Erickson. Newark: Rutgers University Press, 2013," Genocide Studies and Prevention 8, 3 (Fall 2014): 101-102. (O2014 Genocide Studies and Prevention. http://dx.doi.org/10.5038/1911-9933.8.3.9 
recognizes the real differences between these cases, nor distinguishes between Pontic Greeks and western Anatolian Greek population. The same processes of hiding genocide have occurred in Greece, as Pontic communities have struggled long to have their experiences fully acknowledged. Travis also seems to be unaware of evidence by Greeks and Assyrians themselves: the Greek parliament commemorated Turkey's destruction of Ottoman Greeks, but reserved the nomer 'genocide' for the treatment of the Ottoman Armenians. Many historical sources including interviews with Assyrian survivors suggest that genocidal intent among the CUP elite was strongest towards the Armenians. Most importantly, Travis seems to miss the point of the book by committing the same sin he denounces: he disregards the massacres of Yezidis, the mass deportation of Kurds, massacre against the Alevi Kurds of Koçgiri (all during World War I) and the Dersim genocide of 1938. To quote a point cogently made by Adam Jones: in periods of severe political crisis, genocides can be reciprocal (pp.135-6), but Travis' chapter also omits the expulsion and massacre of Muslims in the Balkans during the twin wars of 1912-1913, and the Greek massacres against Turks during their military occupation of Anatolia.

All in all, Hinton, La Pointe, and Irvin-Erickson offer us a useful prism through which to examine and weigh conventional accounts of genocide. The book functions like a photo negative inverter: it reveals coverups and makes the invisible visible. Law, politics, international relations, scholarship, all can play a role in 'hiding' genocides. Up to a certain degree, a critical, detached, and intellectually autonomous position can help uncover them. 